\title{
THE PRINCIPLE OF FORESEEABILITY OF JUDICIAL DECISIONS AS A COMPONENT OF THE RIGHT TO A FAIR TRIAL ${ }^{1}$
}

\author{
Comparative study of three legal regulations
}

\section{Jana Křiváčková ${ }^{2}$ \\ Faculty of Law, Palacký University Olomouc, Czech Republic email: jana.krivackova@upol.cz}

KŘIVÁČKOVÁ, Jana. The principle of foreseeability of judicial decisions as a component of the right to a fair trial. International and Comparative Law Review, 2012, Vol. 12., No. 1, pp. 69-79. DOI: 10.1515/iclr-2016-0079.

\begin{abstract}
The article focuses on the principle of foreseeability of judicial decisions in civil court proceedings, as one of the components of the right to a fair trial in the Czech Republic. The principle of foreseeability of judicial decisions has to be understood as a general term including several requirements on judicial process in civil court proceedings the purpose of which is to avoid surprising decisions which can be seen as one of possible forms of violation of the right to a fair trial. Predictable decision is a decision that follows from a predictable procedure of the court in which the court proceeds strictly according to procedure code using all of the special institutions such as the duty to instruct the participants concerning their procedural rights and duties. The second requirement is to respect the legitimate expectations of the parties regarding the application of law on their case. Participants have the right to expect that their case will be decided accordingly to a legal opinion expressed in a case already decided before the courts. This aspect of the foreseeability of judicial decisions then puts high demands on the ability of courts to deal with situations in which they decide a case differently from the existing case law and thus the decision may be surprising for the participants. This article concentrates on the legal regulation of the principle of foreseeability of judicial decisions on the level of constitutional and civil procedural law. The article also deals with the legal regulation in this area in the Slovak Republic and Germany. The purpose of the article is to compare the legislation on national and international level as well as to compare Czech, German and Slovak legal regulation of the principle of foreseeability of judicial decisions.
\end{abstract}

Keywords: principle; foreseeability; judicial decisions; fair trial

1 This article was written within the project of Student grant competition No. PF_2010_006 (Foreseeability of judicial decisions in civil court proceedings).

2 JUDr. Jana Křiváčková. Lecturer, Faculty of law, Palacký University in Olomouc, Czech Republic. Email: jana.krivackova@upol.cz 


\section{The principle of foreseeability of judicial decisions as a component of the right to a fair trial}

The right to a fair trial is an expression of qualitative standards pertaining to the process of judicial protection of violated and endangered rights and legally protected interests of individuals. It specifies thus in detail how judicial protection should be provided. The standard of foreseeability of judicial decisions is also considered to be a component of the right to a fair trial. The procedure of the court upon providing judicial protection and the court's subsequent decision, that is to say, the main product of the proceeding, may not be surprising for the parties, if there is some legitimate expectation on their part regarding a certain course of the proceeding or regarding a certain decision of the court in the particular case.

The foreseeability of a judicial decision can therefore be understood in several ways. First, a judicial decision must be a product of a foreseeable procedure of the court, whereas the parties must not be surprised by the court's decision with regards to the course of the procedure so far. Second, if the parties follow the current case law upon qualifying their case, the decision must not show aspects of arbitrary deviation from such established practice of the courts, on the contrary, the different decision of the court must be based upon relevant reasons and argumentation that must be explained to the parties in the statement of the reasons. And third, the foreseeability of judicial decisions presumes the existence of legislation showing up such characteristics like understandability and definiteness which are general conditions of foreseeability of its application by courts.

In this article I concentrate on these three aspects of the approach to the contents of the principle of foreseeability of judicial decisions with regards to the differences and similarities of the projection of the principle of foreseeability of judicial decisions in the Czech Republic, in Slovakia and in Germany. My choice of the aforementioned regulations is based, in the case of the first two regulations, on the common history of both the countries which formerly constituted one state, owing to which the legal orders of both the countries still contain similar elements. On the other hand, though, there has been development in the legal regulation since the splitting of the common state, so it would be appropriate to analyze whether the formerly unified regulation has been amended in the course of time and whether these amendments have put both the regulations further apart or the development in both the countries is similar. The German legal regulation shows up similarities with the aforementioned ones due to the fact that the Czechoslovak law was ranked among the same law culture as the German one, even though the latter has not gone through the phase of profound influence of the communist regime the repercussions of which still pose challenge to the Slovak and Czech legal order. Results of comparison of the regulations in these states, with regards to the level of application of the principle of foreseeability of judicial decisions in civil proceedings as a part of the right to a fair trial, 
can then be used upon drawing conclusions regarding the fulfilment of demands on the quality of the provision of judicial protection in the particular states.

If we are talking about foreseeability of judicial decisions based on legitimate expectations of the parties who expect a similar decision in their case in comparison with some analogue case which was judicially decided earlier, we find this principle, to a certain degree, present within all the aforementioned countries. It follows both from the general principle of legal certainty and generally from the principle of equality. These principles are constitutional principles in all the aforementioned states. Judicial practice of courts, however, is not generally and absolutely binding in any of these countries and can change in the course of time; moreover, courts may deviate from the constant judicial practice with regards to circumstances of a case. Then it follows from the approach to the right to a fair trial, though, that there is a duty of the court to deal with the deviation by means of argumentation in the statement of reasons.

The principle of legal certainty is present in the Czech regulation on its constitutional basis in Article 1 Par. 1 of the Constitution of the Czech Republic, the principle of equality can be found in Article 1 of the Charter of Fundamental Rights and Basic Freedoms. On a long-term basis the Constitutional Court considers foreseeability of judicial decisions to be a manifestation of both the abovementioned principles. ${ }^{3}$ The new Civil Code (Act. No. 89/2012 Coll.) involves in its Section 13 an explicit stipulation of the right of parties in civil proceeding to expect a decision conforming with a decision made earlier in an analogue case, and if the court makes a different decision, it must be duly reasoned and the difference must be clarified.

The Slovak legal order does not involve such explicit regulation, however, with the view of the principle of legal certainty included in Article 1 Par. 1 of the Constitution of the Slovak Republic and the principle of equality included in Article 12 Par. 1 of the Constitution the foreseeability of judicial decisions based upon legitimate expectation of the parties is derivable from legal order. Judicial practice of Slovak courts also responds to this. ${ }^{4}$ However, it must be said that there is no absolute liability to case law, courts may deviate from it if there is some reason and the deviation is duly reasoned. Any different procedure would be considered to be violating the right to a fair trial.

In Germany the principle of legitimate expectation and legal certainty, as well as the principle of equality (Article 1 Par. 1 of the Constitution - "Grundgesetz") are based upon the principle of legally consistent state (rule of law). But no direct liability to case law is stipulated anywhere in the legal order. The constant judi-

3 Judgment of the Constitutional Court of November 25, 1999, evidence No. III. ÚS 470/97, Judgment of the Constitutional Court of July 17, 2007, evidence No. IV. ÚS 451/05.

4 See e.g. decision of the Constitutional Court of the Slovak Republic of November 29, 2006, evidence No. III.ÚS 302/05, decision of the Constitutional Court of the Slovak Republic of November 3, 2006, evidence No. III. ÚS 192/06. 
cial practice is of importance upon solving complicated, hard cases. Legitimate expectation with regards to the case law is, however, much less justified in comparison with the certainty of applying explicit regulation included in legislation. The case law can be primarily effective through the convincingness of its reasoning. On the other hand, legitimate expectation can be based upon the constant judicial practice. ${ }^{5}$ Uniformity of judicial practice is thus considered to be a basic condition of foreseeability of judicial decisions. That is why we find an act regulating the procedure of ensuring uniformity of the judicial practice of supreme courts in the legal order of Germany - Gesetz zur Wahrung der Einheitlichkeit der Rechtsprechung der obersten Gerichtshöfe des Bundes vom 19. Juni 1968 (BGBl. I S. 661).

Foreseeability of application of the law is conditioned by clarity and definiteness of the particular regulation. Therefore, if the regulation is unclear or unintelligible, it must not be at the expense of addressee of prescripts, that means, vagueness and indefiniteness of a certain prescript may not justify surprising decisions. This approach can be found in legislation of all the three countries and it also follows from the case law of the European Court of Human Rights to which these states underlie as signatories of the European Convention on Human Rights. ${ }^{6}$

A judicial decision should be a result of judicial proceeding in the course of which the court has proceeded within the frame of procedural rules, in a way foreseeable for the parties. That means that procedural acts of the court should not surprise the parties, the court should arrange the proceeding in a way foreseeable for the parties while respecting the principles of procedural law and the right to a fair trial at the same time. This third view of foreseeability of judicial decisions is closely interconnected with the particular approach to the court's instruction duty. The regulation of the instruction duty is different in the aforementioned states, more precisely; its contents show up certain differences regarding the extent of active role of courts in contradictory proceedings. That is why I concentrate in the following on this particular issue of foreseeability of judicial decisions.

\section{The principle of foreseeability of judicial decisions as a component of the right to a fair trial in the Czech Republic}

Within the frame of the Czech legal order the principle of foreseeability of judicial decisions is present in several places and in several forms. Upon analyzing the regulation of the Czech civil proceeding we see that it involves several fundamental provisions the purpose of which is to avoid surprising judicial deci-

5 See Decision of German Constitutional Court - BVerfG, 1 BvR 2530/05 vom 21.7.2010, Absatz-Nr. (1 - 93), http://www.bverfg.de/entscheidungen/rs20100721_1bvr253005.html.

6 See e.g. Amann v. Switzerland (Application No. 27798/95), Malone v. The United Kingdom (Application No. 8691/79) 
sions. The most profound of these may be the provision of Section 118a Par. 1 and Par. 3 of Act No. 99/1963 Coll., Civil Procedure Code - Občanský soudní rád ${ }^{7}$ that stipulates a special instruction duty of the court in connection with the duty of allegation and the duty of proofs on the part of the parties. According to the aforementioned provision the court has the duty to instruct the parties concerning the fact that they have not yet alleged all conclusive facts or proposed enough proofs proving the allegations. The purpose is to avoid situations when the court would be compelled to dismiss the action only because a party was not aware of its duty to complete its allegations or propose further proofs, that is to say, the party failed in bearing its burden of allegation or the burden of proofs. If the court did not fulfil this duty, the consequent dismissing decision would be unambiguously surprising and released on the base of proceeding which would be considered to be violating the parties' right to a fair trial according to Article 36 Par. 1 and Article 38 Par. 2 of the Charter on Fundamental Rights and Basic Freedoms.

Besides these instructions Section 118a CPC in its second paragraph stipulates another instruction duty of the court which shall be applied in case the court qualifies the case differently from a party, that is to say, the court's legal opinion is different. The object of such an instruction should not be, however, a direct notification of the different legal opinion in the case but it should be an instruction concerning the necessity of completing allegations which are needed on the score of this different legal qualification. If there is no necessity of completing the allegations, that is to say, if the court has enough documents for its decision in the form of allegations foreshadowed by the parties in the course of the proceeding so far, there is no necessity to instruct the parties concerning a different legal qualification of the case, according to the current interpretation of the aforementioned provision of the Code of Civil Proceeding. ${ }^{8}$ Should this instruction duty remain unfulfilled, so such procedure would again be considered to be contradictory to the party's right to a fair trial. ${ }^{9}$

We can see that fulfilment of the idea of foreseeability of judicial decisions in the Czech civil proceeding is achieved by providing the aforementioned instruction duties. However, the court must proceed so that the principle of equality of the parties is not affected. This principle is explicitly expressed in the Czech legislation both on constitutional level and within the frame of CPC. So the court's instruction directed towards one party may not be provided in such a form that this party would be given advantage in comparison with the other contradictory

7 CPC hereinafter.

8 E.g. Decision of the Supreme Court of the Czech Rep. of June 23, 2010, evidence No. 23 Cdo $721 / 2008$.

9 E.g. Judgment of the Constitutional Court of the Czech Rep. of November 23, 2010, evidence No. IV. ÚS 2738/10, Judgment of the Constitutional Court of the Czech Rep. of October 22, 2008, evidence No. I. ÚS 129/06, Judgment of Constitutional Court of the Czech Rep. of October 3, 2006, evidence No. I. ÚS 173/06. 
party. The court has to construct its instruction so that it will not serve as a hint for some of the parties regarding the way this party should take in the trial in order to be successful, but it must help the court acquire information necessary for making a just decision. ${ }^{10}$ The instruction under Section 118a should therefore be provided with regards of the general rule included in Section $5 \mathrm{CPC}$, that is to say, the court in principle provides instructions concerning procedural rights and duties only, not concerning rights based upon substantive law.

\section{The principle of foreseeability of judicial decisions as a component of the right to a fair trial in Slovakia}

The Slovak regulation of civil proceedings is included in the Act No. 99/1963 Coll., Civil Procedure Code - Občiansky súdny poriadok ${ }^{11}$. It is the same norm as the Czech one, whereas there have been many profound amendments since the division of the common state in 1993. In spite of the obvious similarity of both the regulations, we find utterly different regulation of some institutes and there are also newly introduced institutes there that are unknown to the other regulation.

In the context of the foreseeability of judicial proceeding and decision both the regulation of general instruction duty stipulated in Section 5 OSP and even more specifically the provision of Section 100 OSP must be mentioned. Unlike the Czech regulation the Slovak legislative regulation of civil proceeding does not contend any analogy of the Czech provision of Section 118a CPC. That does not mean, however, that the court does not have the duty to instruct the parties of their duty to allege conclusive facts and propose evidences (but, unlike the Czech regulation, the court does not have this duty towards legally represented parties.) The duty of allegation and the duty of proof belong among the basic procedural duties of the parties (Section 101 of OSP), which is why the court has the duty to instruct them concerning their duties. The provision of Section 5 of OSP stipulating the general instruction duty is constantly interpreted as being applicable to the instruction concerning the duty of allegation and the duty of proof as well, in cases when it is obvious from the proceeding so far that from the court's point of view the party has alleged some facts and proposed some proofs but has not presented all the conclusive facts yet or has not proposed sufficient proofs supporting facts alleged by this party.

With the view of foreseeability of judicial decisions the presented understanding of the instruction duty is of crucial importance since upon its fulfilment such situations can be avoided in civil proceeding as a court dismissing an action only due to failure in bearing the burden of allegation or the burden of proof in spite of the fact that the plaintiff has not known at all that from the

10 Similarly e.g. Decision of the Supreme Court of the Czech Rep. of June 23, 2010, evidence No. 23 Cdo 721/2008.

11 OSP hereinafter. 
court's perspective by him or her alleged facts and proposed proofs are insufficient for proving the alleged claim. So in spite of the fact that the Slovak regulation does not involve an explicit stipulation of courts' instruction duty in the case of insufficient fulfilment of parties' duty of allegation and duty of proof, as it is comprised in the Czech CPC, upon interpreting the provision of Section 5 OSP stipulating the general instruction duty we come to the conclusion that this duty involves a duty analogical to the duty stipulated under Section 118a Par. 1 and 3 of the Czech CPC.

The provision of Section 5 OSP prescribes that the court instructs the parties concerning their procession rights and duties. It follows a contrario that the court does not instruct concerning substantive law. ${ }^{12}$ Moreover the court has not the duty to instruct the parties concerning possible interpretation of the substantive law in the course of the proceeding. ${ }^{13}$

The Act No. 384/2008 Coll., which came into effect on October 15, 2011, amended the provision of Section 100 Par. 1 OSP, so that its last sentence in its current diction allows a court to notify to the parties its opinion regarding legal qualification of a case based upon alleged and proved facts, in the course of the proceeding. In this way the court may announce to the parties how it would qualify the case under current circumstances, thus allowing them to react adequately to such conclusion, that is to say, either try to support this opinion of the court by their arguments and procedural acts or, on the contrary, direct their procedural acts more assertively with the view of reversing such opinion of the court. According to the explanatory report referring to the abovementioned amendment the purpose of this institute is to avoid surprising decisions. There is an opportunity for the parties to direct their factual allegations and proposals of proofs in a desired way, which is either further reinforcement of the court in its revealed opinion of the case or reversing such opinion. However, the court is not bound by its revealed preliminary legal qualification and may come to quite a different opinion in its final decision. Such deviation will not be considered to be a surprising decision, though, because it will be a product of further development of the case in the course of which the parties reacted to the preliminary legal qualification of the case by the court and presented further allegations, proofs and arguments. The purpose of the last sentence of the provision is to come in the course of the proceeding to a just and foreseeable decision which reacts adequately to the requirement of protecting the parties' rights.

Section 100 Par. 1 of the Slovak OSP is constructed differently from Section 118a Par. 2 CPC of the Czech CPC. As mentioned before, the provision of Section 118a Par. 2 CPC involves the instruction duty related to the situation

12 Similarly in decision R 20/1994, decision R 38/1994 quotation in Marek Števček \& Svetlana Ficová et al., Občiansky súdny poriadok-Komentár $\$ 5$, (1st ed. 2009), p. 10.

13 Decision SJ 23/1998 quotation in Marek Števček \& Svetlana Ficová et al., Občiansky súdny poriadok-Komentár $\$ 5$, (1st ed. 2009), p. 10. 
when the court holds different legal opinion regarding the solution of the case in comparison with a party and when it is thus necessary for the party to present missing facts. So the primal purpose is not to notify an opinion (which would be something that the court may not do, with regards to the principle of procedural instructing only) but completion of information necessary for unity and for clarification of facts of a case.

The court's process stipulated under Section 100 Par. 1 OSP must then be seen not as the court's instruction duty in the strict sense, but rather as an instrument which enables the court to notify its preliminary opinion regarding legal qualification of the case. The pursued interest here is a quicker and more flexible proceeding of the court in the particular case and also the avoiding of unforeseeable proceedings of courts. According to this rule the court may proceed in this way, that is, the court has not the duty to notify its opinion in all cases but the court may consider efficiency of such process and probability of whether it will contribute to the achievement of the goal of the proceeding.

\section{Principle of foreseeability of judicial decisions as a component of the right to a fair trial in Germany}

The German regulation of civil proceeding, Zivilprozessordnung (ZPO hereinafter) stipulates in its provision of Section 139 special instruction duties of courts which should provide for foreseeability of judicial decisions. Paragraph 1 stipulates courts' instruction duty characterized by hearing the case with the parties both from legal and factual point of view, if such procedure is necessary. This will be the case when the parties have not yet sufficiently described conclusive facts, have not proposed sufficient proofs proving their allegations and have not submitted to the court all related facts and have not made all useful proposals.

Paragraph 2 of Section 139 regulates the instruction duty of the court in case when the court intends to base its decision on a certain opinion which has obviously been overseen or underestimated by the parties, or in case the court differs from the parties in qualification of such opinion. In such case the court must foreshadow its opinion and allow the parties to comment on it. The instruction under Section 2 is used separately when there is no need for the parties to complete their facts, proofs or proposals. The court shall apply the instructions stipulated under both the paragraphs, when necessary. ${ }^{14}$

The described instructions obviously follow the purpose of avoiding surprising decisions, that is to say, rights of the parties should not be violated just because the parties are in error regarding the importance of some facts, proofs or proposals with the view of the decision, or because the parties have overseen

14 Similarly Wagner, C. in Münchener Kommentar Zivilprozessordnung. \$\$1-510c. 3. Auflage. Verlag C.H. Beck, München, 2008. p. 1010. 
a certain aspect of the case that is, on the contrary, seen as crucial by the court. Under the aforementioned provisions the court not only may, but must notify to the parties its legal opinion, that is to say, the qualification of the case in terms of the substantive law. The court may even advise the parties of the possibility of putting objections based upon substantive law, as stated by Wagner ${ }^{15}$, but only when there has been some fundamental base for such an objection in the pleading of the parties.

Upon comparing the German regulation with the Slovak one we come to the conclusion that there are obvious similarities between these two regulations. The Slovak court also has to instruct a party concerning the party's duty to complete conclusive facts and proofs, whenever the court comes to the conclusion that the party has not yet sufficiently described the facts or proposed the proofs. Further, when necessary, the court may notify to the parties its opinion regarding the legal qualification of the case based upon alleged and proved facts so far, whereas this may be done before the decision is pronounced. The court allows thus the parties to express their opinion regarding such qualification and to influence it by means of their further acts. This possibility is not explicitly or exclusively connected with the situation when the court's opinion differs from the party's in terms of legal qualification of the case. In connection with the notification the court may of course prompt the parties to complete facts and proofs. The obvious purpose is again to avoid situations when the parties would be surprised by the court's decision. The German regulation, however, goes even further and directly stipulates courts' duty to notify to parties their different opinion at any moment and to draw parties' attention to those aspects of a particular case which the parties have neglected. Slovak courts must not advise parties regarding the possibility of applying objections based upon substantive law or concrete procedural acts since this would be considered to be contradictory to the principle of equality. In this regard the German court is not limited so strictly and is allowed to do this under particular circumstances, whereas it is still viewed as a procedure nonviolating the principle of equality, but as its manifestation.

Upon comparing the Czech regulation with the German one we come to the conclusion that in spite of some similarities the extent of instruction is different in these regulations. A Czech judge instructs parties when they have not presented conclusive facts or proofs in general and specifically in case of necessity of completing facts when such necessity follows from a difference in legal qualification of the case on the part of the court. However, even though these instructions pertain to a partly foreshadowed legal qualification of the case, the court may not reveal its opinion directly before the decision is made, that is to say, the court may not tell the parties how it would decide the case in the course of the proceeding, as is the case with a Slovak court or a German court which even

15 Wagner, C. in Münchener Kommentar Zivilprozessordnung. \$\$1-510c. 3. Auflage. Verlag C.H. Beck, München, 2008. p. 1008. 
has no other option than to do it. A Czech judge also cannot instruct the parties concerning the possibility of applying concrete procedural acts or objections based upon substantive law, due to the conflict between such procedure and the principle of equality expressed in the Constitution of the Czech Republic, in the Charter of Fundamental Rights and Basic Freedoms and in Section 18 CPC.

\section{Conclusion}

In all of the discussed countries the principle of foreseeability of judicial decisions is considered to be one of the components of the right to a fair trial. The foreseeability of judicial procedure, including the decision itself, is achieved through the court's duty to instruct the parties. From this point of view all the regulations of the instruction duty follow the same goal, that is to say, avoiding the situation when a judicial decision would be surprising for a party that has not been informed of the fact that according to the court's opinion the party has failed in bearing the burden of allegation and the burden of proof, or the party, unlike the court, does not consider an aspect of the case to be substantial or is not aware of it's existence. However, the content of this instruction duty is different within the compared regulations, first of all through the range of possible excess of such instruction into the frame of the substantive law. The principle of foreseeability of judicial decisions, and in its context the fulfilment of the instruction duty is accompanied here by the principle of equality of the parties (i.e. equality of arms) as one of the fundamental components of the right to a fair trial. The way of understanding the content of this principle is also different in the particular regulations. In the Czech civil procedural law the regulation of the instruction duty is strongly influenced by this principle, so that the court must not instruct a party to the degree when equal position of all participants of a particular proceeding would be affected. That would be the case if a Czech judge would proceed the same way as a Slovak or German judge, and notify her or his opinion regarding the legal aspects of the case to the parties before the announcement of the decision or if the judge would instruct the parties concerning particular procedural acts they are entitled to. In spite of its connection with substantive law the instruction duty under Section 118a CPC should still be perceived as an instruction concerning procedural rights and duties, not concerning rights and duties arising from substantive law.

In relation to the new regulation of civil procedural law which is actually being prepared in the Czech Republic I would prefer it to be inspired by the German regulation which is long-term steady and precisely formulated, however, this can only be said regarding the non contentious proceedings where there are no parties to the dispute and where the object of the proceeding is not to solve a conflict but to arrange relationships in the future. In such proceedings the court has the duty to find out facts and proofs (participants do not have to bear the burden of proof and burden of allegation); however, co-operation of parties 
is counted with and requested. In this type of proceedings neither preliminary notification of legal qualification of the case nor reference to the possible application of certain procedural acts, or even objections based upon substantive law (presuming that there exists a base for them formed upon previous allegations) could be seen as a violation of the principle of equality.

In my opinion it is not necessary to broaden the instruction duty of court regulated under Section 118a CPC to the extent to be found in the Slovak or German civil procedure law if it comes to contentious proceedings. The court in contentious proceeding fulfils the function of an unbiased third party that on the base of submitted facts and proofs makes a decision in the case. According to the current conception of contentious proceedings in the Czech civil procedural law under which the parties stand in contradictory position and bear the main responsibility for clarification of facts in the proceeding, such amendment would not be possible without transformation of the whole regulation 